\title{
Documenting Selected Artefacts of the Royal Regalia of Akwamumanhene
}

\author{
Andrew Richard Owusu Addo (MFA) \\ Kwame Nkrumah University of Science and Technology \\ Dr. Steve Kquofi (PhD) \\ Kwame Nkrumah University of Science and Technology \\ Dr. (Mrs.) Nana Ama Pokuaa Arthur (PhD) \\ Kwame Nkrumah University of Science and Technology
}

\begin{abstract}
This study which identifies and reviews selected artefacts of the Akwamuhene royal regalia was conducted at the Bogyawe palace in Akwamufie. The research tools employed were questionnaire, observation and interviews to collect and investigate relevant cultural knowledge on the royal regalia of the Akwamuhene. Using the appropriate research instruments, for purposeful analysis and interpretation, the artefacts were documented hence, served as a means of preservation. There were 65 respondents who were interviewed using an interview guide and 30 of respondents were given questionnaire. The respondents for the study provided names, myths, history, philosophies and significance of the artefacts that make up the royal regalia. The study thus focused on selected royal regalia belonging to the Akwamuhene comprising a variety of royal artforms and monuments such as deities, drums, clothes, palanquins, stools, chairs, Akyeame (spokespersons) staff, swords and sword ornaments, traditional sandals, headgears, jewellery and platforms.
\end{abstract}

Keywords: Regalia, Culture, Symbolism, Deity, Drum, Head Gear, Stool House, Keys

DOI: $10.7176 /$ RHSS/10-10-01

Publication date:May $31^{\text {st }} 2020$

\section{Introduction}

Artefacts have been with the human society from ancient times and the use of these artefacts, as artforms, as a medium of communication has been with indigenous Ghanaian cultures since their existence and serve as evidence of past historical events. In support of this, Prown (1993) opines that artefacts are unique historical sources that are seen as authentic primary sources for research. In Ghana, artefacts form an important part of communication and serve as a symbolic language reflecting a way of life and a means of documenting cultural values and traditions.

Kyeremamten (1964) defined regalia as "adornment and implements worn or carried by kings, chiefs, queen mothers and other royals and court members". In agreement with this assertion, regalia, in essence, sets royalty apart from 'ordinary' folks and they carry messages in the form of symbolism. In Ghana, artefacts among others are seen to include royal regalias such as apparels, furniture, tools and armoury, as well as symbols of authority and office. These are made up of body adornments such as clothes, sandals, jewellery, headgears and amulets. Included in this collection also are stools, flywhisks, drums, swords, footrests, umbrellas, talismans, linguist staffs and musical instruments. These artefacts considered as royal regalia, are used primarily by the chief to express the values of his people as well as the responsibility bestowed upon him by his ancestors. The regalia used by a chief, in essence, conveys information about the people he leads as well as other verbal and visual messages. The historical and cultural artefacts of chiefs' regalia convey visual and verbal messages mostly developed from cultural beliefs and symbolism. These messages are usually made up of proverbs and beliefs which have been codified in the secret language of the people with historical and cultural implication. These messages possess deep philosophical, socio-cultural and historical values.

The Akwamu state is one of the most prominent states in the larger Akan state. Akwamuhene is a term that is translated as "king or chief of $A k w a m u$ ". In Ghana, a chief in the northern part of the country adorns himself in accordance with the culture of the area. Likewise, in the southern part where the use of stools and traditional cloths are part of cultural practices, the regalia are fashioned along the lines of the respective culture. The royal regalia of a chief is of extreme importance as they are composed of both symbolic and functional artefacts with deep philosophical values as well as rich historical backgrounds influenced by the culture of the people. The regalia identifies and shows the importance and authority the chief has among his people. Several intellectuals like Amenumey (2011), Wilks (1997), Addo-Fening (1997), Ward (1948) and others have conducted historical researches on the origin, migration and the rise and fall of the Akwamu State. However, none of these scholars has specifically delved into the royal regalia of the Akwamumanhene (Akwamumanhene as he is sometimes referred to, which means king or chief of the Akwamu state) and its implication on the people of $A k w a m u$. These artefacts, if not fully documented may cause a great loss of valuable historical and cultural knowledge which will be of great 
essence to future generations in order to preserve the cultural heritage of the people of $A k w a m u$.

\section{Methodology}

Data collection instruments used included a questionnaire, observations, and semi-structured interviews using prepared interview guides. It also included discussions of selected royal regalia, which the custodian of the royal regalia had granted the researcher permission to observe and record relevant information. The use of the purposive sampling method was employed to gain the right and needed information for the purposeful interpretation and analysis of data. The latent and sematic coding procedure was used to generate the themes for analysing the data collected

\section{Results and Discussion}

For the sake of clarity, Akwamuhene and Akwamumanhene are used to mean the same thing (king of Akwamu) in the study.

\subsection{Royal Regalia of Akwamumanhene}

The general understanding gathered from Akwamu during the period of the study was that the concept of royal regalia and its definition goes beyond what the king adorns himself with. In that circumstance, regalia includes everything that the king uses in the performance of his duties and responsibilities such as artefacts, ornaments he adorns himself with as well as ornaments worn by those close to him that protects him and communicate from the kingdom to the people (Nana Samenhyia, personal communication, July 9th 2018). These include those used by the linguist, orderlies, priests, drummers, executioners (Nana Kwame Boadu II, personal communication, 12th August 2018).

In accordance with Nana Samenhyia, the consensus throughout the various interviews was that the people of Akwamu see the royal regalia of the Akwamumanhene as all things used by and for the king in the performances of his duties. These include but not exclusively, drums, stools, deities, clothing, chairs, swords, staffs, animal skins, horns, palanquins and footrests. Also considered as part of the regalia are the platforms that the king sits on during various occasions. Aside from the platforms and footrests, there are various types of mats used by the king and this was extended to where the various stools and some deities are kept which are consecrated and are also considered as part of the royal regalia. There are other types of regalia that are not used often and are only brought out on special occasions, such is the Christiansborg keys, feathered hat, sash, swords, black stools, special clothes, native sandals and other state property that are officially put under the chief's custody. Some of these, are not custom inclined however for certain special reasons find their way in the security of the Akwamuhene. For example, the Christiansborg keys, the feathered sash and the sword were said to have been donated to the Akwamuhene by King Frederick of Denmark and these are only brought out during the Odwira festival (A week-long period of traditions and rituals performed to cleanse the town, the people and the ancestral Stools and deities. It also involves the celebration of "new Yams") and other important durbars and festival of the people of Akwamu. These are brought as state regalia and they are meant to show the competence and authority of the Akwamuhene not only in the Akwamu state but to also depict his recognition in the nation and the world.

\subsection{Classifications of the Akwamumanhene Regalia}

The emphasis of this paper is to document selected artefact of the royal regalia of Akwamuhene which are considered as 'uncommon'. This is mainly based on existing literature regarding the people of $A$ kwamu, reviews and responses from the data collection exercise for this study. For discussion sake, these regalia have been placed in a number of categories. The categories are the deities, drums, jewellery, headgear, stool house, foot mats, keys, platforms, staff and horns. These became prominent as almost all respondents saw the royal regalia of the Akwamumanhene as not just the common jewellery that all chiefs possess but those other facilities that are not directly used by the king. Some regalia are under the care of other chiefs and attendants who work in the name of the king.

\subsection{Deities}

There are a number of deities that are considered as part of the Akwamumanhene royal regalia such as Tutu abo (located at Anyensu), Amampon Kofi, Sawa (located at Perseh), Bosom ayenso (Bosom asu), Odum gyakata and Gyebum (a powerful deity for the executioners). 
Table 1: Showing the list of deities, their translations in English and the purpose they serve

\begin{tabular}{|l|l|l|}
\hline Name of Deity (Akan) & Translation (English) & Purpose \\
\hline Akwamu Odwura / Apafram & Akwamu purification & Purification rituals \\
\hline Tutu abo & Uprooting stones & War god \\
\hline Bonsam bo & Devil's stone & Purification rituals \\
\hline Bosom asu/ Bosom Ayenso & An idol called Ayenso & Purification rituals \\
\hline Odum Gyakata & & Mediator \\
\hline Gyebum & & Fortification \\
\hline Kwame Buor & A stone called Kwame & Enstoolment rituals \\
\hline Wontumi (Ogyeabour) & You can't (reflector of bullets) & Protection \\
\hline
\end{tabular}

- Akwamu Odwira or Apafram

The Apafram is considered as a deity and presented in the form of a relic that contains the heads of conquered and captured kings and chiefs during wars. These leaders were beheaded and their heads kept in this container (personal communication 18th February 2019). This can be found in Akwamufie, specifically at the Bogyawe palace. Apafram is used for purification rites as well as consultation on all matters as the spirits are ready to act on the supplication of his people.

The Apafram looks like a bowl and made of the shell of a large sea turtle which has been hardened through drying and serves as a container for carrying the heads of overpowered and captured kings. The Apafram is kept in a room which has neither lights and nor windows. However, in personal communication, Katongo said the various remains of the dead could be identified with the help of the ancestor themselves (Katongo, personal communication, 10th March 2019). Upon notice and arraignment, Apafram can be consulted on any day even though the deity has a high number of visitors during festive seasons.

\section{- Tutu abo}

In a personal communication with Nana Ofei Boadu II, who is the Chief's adviser for the Akwamuhene on the $20^{\text {th }}$ of January 2019, he indicated that tutu abo is arguably the most important deity of the people of Akwamu and in extension the Akwamumanhene. His assertion was based on a historical fact told him by his grandfather who was once the Nifahene, translated in English as 'right-wing head' of the Akwamu traditional area. This story was corroborated by other chiefs such as the Gyaasewahene as well as the Queen of Akwamu, Nana Afrakuma II.

Tutu Abo is a War god and can be located in Anyensu, one of the villages within the Akwamu Paramountcy. It is primarily used for healing and protection. Tutu Abo, just like one of several other deities, it is vertical in shape and moulded in red clay. It is roughly 25 inches high and 8 to 10 inches thick at the widest point. At the back and crown, it is painted white colour. The nose of Tutu abo is a long red ochre mark with a thick black mark placed horizontally on the left cheek. Tutu Abo can be consulted at any time.

\section{- Bonsam bo}

Bonsam Bo is a deity that sits right at the entrance of the Bogyawe palace in Akwamufie. Due to its location (the main entrance of the Bogyawe palace), the Bonsam bo serves as a conduit between the people of Akwamu and the ancestral spirits. It is used for purification rites for the king. Purification rites done besides this deity means that the purification is essential but unlike other rites cannot be performed in the stool room, hence, it is done on the spot where the deity is located. On the facial, it looks like a kind of stone buried halfway in the ground. It is covered by a barrier made of a metallic chain.

In a personal communication with Nana Samenhyia Darko II, the Gyaasewahene who acts as the household chief at the Bogyawe Palace of Akwamu in agreeing with the queen mother of Akwamu, Nana Afrakuma II, indicated that every year during the celebration of Apafram (Odwira festival) sacred water is brought from all the deities such as Mfodwo, Mpem Kwadwo, Obohene and Tutu abo (who are all gods of war in Akwamu) to the palace for the king's purification and the purification of the whole Akwamu state. To appease calamity, a ram is also slaughtered where the deity is positioned. On other occasions such as the installation of two particular chiefs, the king is also expected to sit at this same spot for certain chiefs such as the Werempimhene (one in whom I have placed my trust) and Gyaasewahene who acts the household chief to swear allegiance to him when they are being installed. The Bonsam bo deity reminds the people of Akwamu to live a sanctified life. It also reminds them of the fact that on a yearly basis, there is an opportunity to appease the gods for clemency.

\section{- Bosom asu (Bosom Ayenso)}

Bosom asu is a deity and by tradition under the care of the Queen mother of $A k w a m u$, hence is currently under the care of Nana Afrakuma II (the current Queen of Akwamu). This deity sits in the middle of Akwamufie (home of Akwamu people). It is about a hundred metres away from the queen's palace. It is a white painted walled place in the middle of Akwamufie. It also has a very big Odum (Milicia excelsa) tree in the compound as a result of a prophecy given by Okomfo Anokye that, as a sign of Akwamus survival, an Odum tree must grow by itself in the middle of the town. It is one of the deities used for purification in Akwamu.

The deity is not open to public viewing but as stated earlier, it is walled and always painted white. On every 
Tuesday all royals are supposed to pay homage to the deity with a visitation.

\section{- Odum Gyakata}

This is a deity who acts as the linguist to the other deities and spirits without whom you cannot approach the others in the stool room. Odum Gyakata is kept in the stool room away from the public and it is consulted as and when necessary. This was what the Akwamumanhene's Tufuhene said when asked about the involvement of Odum Gyakata in the daily life of the Akwamumanhene. The Queen (Nana Afrakuma II) also confirmed this accession that Odum Gyakata will always be consulted when the king needs to put on the Mahoney cloth. Odum Gyakata is in a form of suman which in African traditional religions, and mostly in the Akan societies, is an object that is used as a talisman or charm because of its perceived spiritual power.

\section{- Gyebum}

Gyebum is part of the executioners' collection and a deity which is under the custody of the Adumhene who is in charge of the executioner and security. In ancient times, various rituals were performed for this deity among which included human sacrifices. Newly born babies with their umbilical cords still attached were prepared and offered as sacrifices to the deity. However, currently, newly born sheep are used in sacrifice instead of human beings. Gyebum is one of the powerful deities in Akwamuman and can be located in Akwamufie.

Gyebum, as a deity, apart from other citizens going to him for help with all kinds of things, it is a place where the executioners in Akwamu go to fortify themselves. It is a place where the spirits of the ancestors have total control such that in personal communication with Nana Ofei Boadu II, the executioners are notified spiritually anytime someone goes close to the vicinity.

\section{- Kwame Bour}

This is a special stone where the Akwamumanhene is installed. It can be located at the entrance of the main township of Akwamufie and found on the right-hand side in front of the palace of the Adumhene.

The site where Kwame Buor is located is where special rituals are performed for the enstoolment of the king (Nana Ofei Boadu II, personal communication, $10^{\text {th }}$ February 2019). At first sight, it looks like a big boulder stuck in the ground and its purpose is really felt when there is supposed to be an installation of a new chief of Akwamuman.

\section{- Wontumi (Ogyeabour)}

This is a deity attached to Mahoney (Ogyeabour) which is a bulletproof cloth. The literal meaning of the name Ogyeabour is a reflector of stones/bullets with no damaging effect. The deity Wontumi is kept in the Bogyawe Palace and this was what the Gyaasewahene said when asked about the involvement of Ogyeabour in the daily life of the Akwamumanhene. The queen mother also confirmed this accession that Wontumi (Ogyeabour) will always be consulted when the king needs to put on the Mahoney cloth

\subsection{Drums}

Drums form part of the second category of identified regalia. All the divisional chiefs have their twene sin (short drum), which is played according to a particular sound and message. The prominent drums are indicated in Table 2 and discussed in detail subsequently.

Table 2: showing different kind of drums for Akwamuhene's use

\begin{tabular}{|c|c|c|}
\hline Name of Drum (Akan) & $\begin{array}{l}\text { Translation } \\
\text { (English) }\end{array}$ & Purpose \\
\hline Mpcbi & $\begin{array}{l}\text { Never desire for } \\
\text { one }\end{array}$ & Commitment and determination \\
\hline Prempe & & Summon chiefs or announce a particular occasion \\
\hline Krenku & Announcing to kill & To announce execution \\
\hline Aprede & & Communication medium between players and King \\
\hline Fontomfrom/Atumpan & & $\begin{array}{l}\text { Provides music at ceremonies to honour Akan chiefs and } \\
\text { during royal processions. }\end{array}$ \\
\hline
\end{tabular}

\section{- Mpebi}

$M p \varepsilon b i$ is a very short drum about two and a half feet tall which has been in existence for a couple of centuries. And considered as part of the collection of Akwamumanhene's regalia. The drum can be found in the Bogyawe palace museum. Currently, there are no wars among kingdoms as in the past times such that apart from it being used as a symbol commitment and determination, its original purpose has been shifted.

At first glance, it looks rugged and dirty probably due to its age and what it has been used for. A number of jawbones hang off the edges. These jaw bones are the jaws of earlier chiefs (warriors) who led the Akwamu into wars and battles after swearing to the ancestors but failed to conquer. With time, the edge of the hollow wood has worn off; due to this, the animal skin is not able to cover the drum properly. The ropes securing the membrane and the wooden part together has also aged. 


\section{- Prempe}

The prempe is a talking drum solely for the Akwamumanhene and always kept in a room close to the entrance of the palace. It is a drum that is used to summon chiefs or announce a particular occasion to the people. According to oral history, the prempe drum was said to have been instituted at Twifo-Hemang to assemble soldiers during wars and to summon the people to important meetings in time of peace. Apart from the prempe drum announcing the presence of the king, it serves as the timekeeper because the people are able to recognise the presence of the king in the palace.

The drum is always covered when being transported as well as when it is being played. However, from the look of the covering, it can be estimated at two feet tall. At the Bogyawe palace, the prempe drum is the first to be played to wake the Omanhene (chief or king of the state) up from sleep and the last to be played when he is going to bed. The drum is also played to lead the king of Akwamu into a public gathering to announce his presence.

\section{- Krenku}

Krenku is a short drum which announces the application of the death penalty. Krenku literally means 'announcing the departure to execute'. Therefore, when the krenku drum is beaten three consecutive times, it means an announcement is being made that someone is to be punished for a deed committed.

This drum is used by the Adontenhene (leader in a traditional war formation) in trust of the Akwamumanhene. The Krenku drum is basically used to announce execution. This came about after a chief exhibited insubordination; he was beheaded and his knee was hanged on the krenku. After any judgement that ends up in a death sentence, the Adontenhene who acts as the interior head and the one who goes in front of the army in a war formation, will go into the merits of the case again and when he is satisfied with the judgement the krenku drum is played (Nana Ofei Boadu II, personal communication, $20^{\text {th }}$ January 2019).

The krenku drum apart from it being used to announce the death penalty, it comes before the prempe is played during major Akwasidae (a festival celebrated on a Sunday by most Akans once every six weeks) and during Odwira which means purification in English.

\section{- Aprede}

Aprede is a set of short drums and a number of bamboo sticks played only for the king as a means of communication. Between the players and the Akwamumanhene. The set of Aprede is kept in the palace in a sacred room with other drums. In the act of playing, the players are completely concealed from the public. The playing of the aprede is accompanied by special songs that are sung while the king sits in state. These songs are composed and selected based on the occasion. The Aprede drum is always shielded both when transporting and when being played but can be estimated at two feet tall.

Oral history has it that, in ancient times, when the aprede drums are set behind the king, the entire band of players were covered with a cloth to conceal their identity and how the drums are played. The drum was also covered during transportation and the sound of the drum can only be heard. This practice of setting up the ApredE behind the Akwamumanhene is still being done.

\section{- Fontomfrom/Atumpan}

These are large drums made up of two very large ones that are played with two medium ones and about two or three smaller ones. In a personal communication with Nana Ofei Boadu II, the Tufuhene meaning chief advisor of the chief of the Akwamumanhene, on $12^{\text {th }}$ January 2019, the significance of the metal piece is to announce the presence of the king and also depict to his people that he is fearless. The set of drums is kept in the palace courtyard and brought out in the sun occasionally to make the membrane dryer. The drums are played to create a rhythm for the dancer as the type of dance also can be used in communication.

It is made up of a pair of male and female talking drum. In times past, the drum was covered with elephant ear skin but currently, an antelope or cow skin is used for the covering. This is by far the largest of the Akan drums, normally five feet high and 2 feet wide and played by two drummers. The fontomfrom is also not played alone but together with the atumpan talking drums and a number of smaller drums. One peculiarity about the fontomfrom owned by the Akwamumanhene it that, it has a metal piece attached to the animal skin which gives a different sound when played.

The drum is carried and played for the king to dance to when he is in public. Aside from the king, these drums can also be played for members of the general public. However, before they are played for anyone else, the drums are placed on a frame that tilts the drums away from the drummer; they are played in pairs with the 'male' drum to the left and the 'female' drum to the right. The drummer plays by standing behind the drums with two long sticks. These sticks are made from the joint of a branch.

\subsection{Stool house (nkonwa fie)}

The Akwamu state has a number of stools. The most prominent is the male stools (ancestral or blackened stools) that have been used by ancestors of the state. The Akwamu male stools represent the soul of the state and are a symbol of their unity and permanence. The Akwamu male stools are revered as sacred objects not to be publicly sat on. The sacred stools are kept in the stool house (nkonwa fie) at the palace of the Omanhene meaning the chief 
or king of the state. Various ancestral stools are kept in commemoration of all chiefs who die on the stool.

\section{- Stools}

Among the collection in the Akwamu palace museum is a stool with bells which is only used during the installation on an Akwamumanhene. The stool is said to have been in existence and use since approximately 1468. During the installation of a new king, he (the new king) is helped by the kingmakers on each side as they gently place him and lift him off the stool three consecutive times. Only then, is the new king deemed to be installed; this, therefore, makes the stool an important aspect in legitimising one's kingship.

\section{- Asipim chairs}

The Akwamu developed the concept of Oman (state), after introducing a kind of stool which has four legs into the kingship system. However, other Akan and non-Akan tribes copied the new innovation. Like most other Akan chiefs, the Akwamumanhene publicly uses chairs instead of stools during festivals, durbars and other official functions (Nana Ofei Boadu, personal communication, November 17, 2018).

Three significant public asipim chairs used by the king were identified. The first of it is the Oman agua meaning the state stool in English. It has the emblem of the Akwamu state, which is the lion spitting fire and standing on a stool. The stool is in three parts combined into one asipim chair. The upper part has the lion spitting fire and it is portrayed as standing on the second part. The second part displays the traditional stool known as the asesegwa having two swords laying on it. The third and the lower part shows a European styled chair. The armrest of this chair is curved to form the head of a lion, and the back where the king's body rests has a carving of the adinkra symbol Bi nka bi which means bite, not one another.

The second asipim used by the king has the emblem of the Aduana clan which is a dog spitting fire and standing on a stool. This is because the symbol of the clan has to be on the kings' official seat to show his status as the head of the clan. On the asipim chair, both the dog and the stool are circled with twigs in a loop representing the topmost part of the chair. The second part is a representation of horn blowers and gongon beaters. This is joined to the seat which also has adinkra symbols carved on the sides.

The third asipim which two dogs spitting fire standing on it and the dogs have their tongues touching each other. On the backrest of this chair, there are carved images of animals such as lions, horses and elephants. The seat of the chair is supported by two dogs who are also spitting fire. This third stool is what the Akwamumanhene normally sits on when the Dormaahene meaning the chief or king of Dormaa in English visits him in his palace.

\section{- Footstools and mats}

These are also considered as part of the royal regalia of the Akwamumanhene (Nana Ofei Boadu II, personal communication, $12^{\text {th }}$ January 2019). The footrests and mats are usually made from the skins of animals. These are used by the king when he sits in state. Among the people of Akwamu, like other indigenous Akan tribes, when the king sits in state his feet are not meant to touch the floor hence the need for the mats and footrests. This is because it shows the status of the king as it distinguishes him from others in a public gathering. The most common animal skin mats used by the Akwamumanhene are those made from crocodile skins, lion skins and tiger skins. Among the others are sheepskin mats which are said to signify the humility of the king. While sitting in state, the sheepskin mats and lion or tiger skin mats are placed on the floor for the king. This is symbolic of the fact that the king has dominion and power both at home and abroad (Nana Ofei Boadu II, personal communication, 12 ${ }^{\text {th }}$ January 2019).

\subsection{Clothing and accessories}

- Mahoney cloth (Dgyeabour)

Mahoney is a cloth (ntama) made out of lion skin and cowries and dates back 400 years. It is traditional bulletproof clothing worn by all kings of Akwamu during wars. The origin of this cloth was from a time that Nana Osei Tutu I (the then king of the Asante kingdom) went to Akwamu to learn about tradition and culture. Before his departure from Akwamu, Ansah Sasraku (the then king of Akwamu), gave him war regalia known as batakari kese meaning big smock in English to protect him on his journey back and during other wars. When Ansa Sasraku presented the regalia to Nana Osei Tutu I, he (the Akwamumanhene) swore not to wear batakari to war again. The absence of the batakari kese led to the development of the Mahoney which was also fortified with the spiritual powers and protection against evil during wars. The Mahoney is however believed to be more powerful than the batakari kese given to Nana Osei Tutu I (Nana Ofei Boadu II, personal communication, 12 ${ }^{\text {th }}$ January 2019).

\section{- Danta}

This is an undergarment worn beneath the mahoney cloth. The king is not supposed to wear any kind of undergarment except this particular danta (the name given to a piece of cloth in Akan used as underwear to cover the loins of the wearer) which was made purposely for the mahoney. There is also a waist bag made from the skin of the cheetah. This was part of a donation from an Asantehene Nana Karikari in appreciation of the numerous supports given to Asante by the Akwamumanhene.

\section{- Kente}

The first kente cloth created was made from a white cotton fibre called Indigo and the Akwamumanhene is believed to have one of the first kente cloths ever produced (Nana Samenhyia Darko II, personal communication, $18^{\text {th }}$ 
February 2019). Included in the king's collection are priceless cloths for royalty from the Far East from around $1800-1850$. There are three of these clothes that are showcased to the public. The first of these kente cloths are predominantly red and has frails attached to the side as well as embroideries on the cloth itself. The designs in the cloth include a sword and a checked pattern as well as other abstract designs. The second of the kente cloths is predominantly brown in colour and also has embroidered star-like designs with a varied arrangement of triangular shapes. One other design embroidered in the adinkra symbol called "funtunfunafu" (Siamese crocodile) which is a symbol of unity and diversity, a design having two crocodiles sharing one stomach and a combination of semicircles and squares. The traditional colours of the Akwamu state, that is, green and black have also been used in this cloth. The third royal cloth is from the Far East and is purple in colour. This also has frails at the edges with crescent-shaped motifs embroidered in the cloth including images of the full moon.

\section{- Crossbelt (nbiemu)}

The cross belt ('nbiemu'), and the feather that is only worn by the king or the "soul" or the decoy of the king who is a person meant as a distraction, and to hide the king during the war from a group or individuals who might be looking for him. The appearance of the cross belt anywhere, announces the presence of the king. The cross belt is made up of a twin metal bell (gong-gong) which is a handheld, two-note iron clapper bell, beaten to alert people and a band that is worn across the upper torso. The band is of cotton material on which the twin bell is hanged.

\section{- Ascndi headgear}

This headgear is only worn when the king sits to judge cases in the palace. This headgear is made of talismans and the shell from the sea turtle because of the toughness of its shell that makes it difficult for other predators in the sea to feed on it. It has a flattened top with stuffed (suman) which in African traditional religions, and particularly in the Akan societies, is an object that is used as a talisman or charm because of its perceived spiritual power is sown wax print band. Attached to the stuffed material are the talismans empowered with spiritual forces that allegedly helps to sanitize the mind of the king and serve as a conduit between the spirits and the king (Nana Samenhyia Darko II, personal communication, $18^{\text {th }}$ February 2019).

\section{- Adedi headgear}

This is a special hat worn by the king on one day only; the day of his enstoolment or installation. This headgear is made from stuffed fabric sewn together into a band. Attached to this headband are talismans empowered with spiritual powers that are meant to possess the king. This headgear like the other serves as a conduit between the spirits and the king (Nana Samenhyia Darko II, personal communication, $18^{\text {th }}$ February 2019).

\section{- Fly whisk (Bodua)}

This whisk is made up of the tail of an animal tied to the end with leather or a strong rope. The leather is used to tie and hold the top part of the tail to allow the free movement of the lower part. Attached to the end with the leather covering is a loop made of the same leather to help secure it in the hands of the holder, that is, the king. Attached to the whisk are other items such as talismans made of various kinds of bones put together in an enclosed pouch. This pouch is normally made of either sacred cloth or animal skin (Nana Ofei Boadu II, personal communication, $12^{\text {th }}$ January 2019).

\section{- Swords}

The swords are used by the king's messengers due to the symbolic nature of the various heads attached to the swords. These swords are made of forged iron with wooden handles of different shapes and colours. The blades of the swords are designed to send messages just as depicted on the handles attached to them. The blades are always painted with black pigment mixed with local preservatives to keep the swords in good shape. There are two main kinds of swords in the collection of the Akwamumanhene (Nana Samenhyia Darko II, personal communication, $18^{\text {th }}$ February 2019). The first group are the ones held by the king's orderlies when the king sits in state during durbars. These orderlies sit in two rows in front of the king holding these swords. The second group of swords are the ones given to the king's messengers on assignments skin (Nana Ofei Boadu II, personal communication, $12^{\text {th }}$ January 2019).

\section{- Horns}

The horns of the Akwamumanhene are made from elephant tusks. Some are kept in their natural states and sometimes polished while others are covered with animal skins. The horns have chains and metal plates that are hooked to the smaller part for easy handling by the horn blowers. The horns are blown early in the morning when the king wakes up from sleep and blown again when he is going to sleep.

\subsection{Palanquin}

The palanquin of the Akwamumanhene is believed to be the oldest handwoven palanquin in Ghana which has been in existence for 350 years (Nana Samenhyia Darko II, personal communication, $18^{\text {th }}$ February 2019). The whole frame of the palanquin is made of wood and the joints are tied together with ropes from trees. The covering and body are made of long grass that has been woven and the inside is lined with a thick woollen-like material. There are three loops on each side for the carriers to use; these loops are made of the elephant's skin. 


\subsection{Apem Adaka}

This is a wooden airtight box which is said to have been in use since time immemorial. It is said to have been used to store gold weights, gold nuggets and gold dust (Nana Samenhyia Darko II, personal communication, $18^{\text {th }}$ February 2019). The apem adaka as the name implies literally means 'a box containing a thousand'. The wooden box has become a stool property because it was carried by the ancestors of the Akwamu from Southern Sudan (where the Akwamu trace their ancestry) and dates as far back as $1200 \mathrm{AD}$. The box is made of wood and has halfround tacks have been arranged diagonally from one corner to another.

\subsection{Christiansborg keys}

In the traditional setting, the Christiansborg keys are locally referred to as Dom nsafe (keys of the state) or Osu abankese nsafe meaning Osu government keys in English. The Christiansborg keys, which were initially kept as war trophy, gained the status of regalia by becoming Akwamu property after the event of June 1693 when Asamani together with about 80 armed men pretended to be traders and entered the castle, but turned, later on, to attack the Danes using the hidden ammunitions given them to test the merchandise preceding purchase and as has been established by Anquandah (1999) and van Dantzig (1980). In order to protect its history, the keys were accepted and made part of the royal regalia of the Akwamumanhene. During installation rites of any new occupant of the Akwamu stool, the bunch of keys are shown to the newly enstooled king as one of the states regalias after sacrifices have been made to the spirits of Akwamu. Like all other regalias, the Christiansborg keys becomes the responsibility of the king to ensure its safety against destruction and theft. On occasions when the keys are brought out, it is put in the hands of an Ahenkwaa (chief's servant) dressed in white calico, who sits in front of the chief. The bunch of keys is usually tied with green cotton material. It is worn on the neck like a medal by the Ahenkwaa when it is to be shown to the public on certain occasions. The servant, who wears the bunch of keys, must put on a traditional cloth lowered to the chest level to make the keys visible to all present.

\section{Conclusion}

A new dimension came up while conducting this study, this is in relation with Blumer's symbolic interactionism where people relate to symbols based on the meanings assigned to them by the society through social interaction nonetheless open to interpretation. This interpretation, in the case of the Akwamu, was the incorporation of deities in the collection of royal regalia that is applying one of the basic tenets of symbolic interactionism stating that meanings are continuously formed and re-formed by interpreting processes during interaction with others. This was put forward strongly by the subordinate chiefs and kingmakers with corroboration from the elders who unanimously agreed with the chiefs. It was also revealed that war spoils were an important part of the royal regalia to the extent that some tools of trade and commerce were included in the regalia. More value was also placed on older artforms than current ones. In essence, the inclusion and acceptance of deities and unmoveable objects was a way of understanding the people of $A k w a m u$ with respect to their royal regalia after interacting with them. This is in agreement with Ampene and Nyantekyi III (2016) that, interpreting regalia as a collective symbolizes royal power and the collective property of the state, which is not the sole property of the reigning king. Thus, all items included in regalia are considered stool property, usually called the agyapade (inheritance) in Akan.

This study attempted to document some of the royal regalia made available and that are used in the Bogyawe Palace and also by the Akwamuhene. In so doing the study concluded that, as every royal regalia have specific roles they play, they can be deemed as functional and ritual objects with symbolic connotations that help the people of Akwamu relate better with their ancestors and deities. This makes the royal regalia of the Akwamumanhene documentary evidence of the history and cultural values of the people.

\section{References}

Anquandah, J., 2006. National Commission on Culture Website. [Online] Available at: http://www.ghanaculture.gov.gh [Accessed 14 November 2017].

Ayensu, E., 1997. Ashanti Gold: Ghana. s.1.: Marshall Edition Developments Ltd.

Blumer, H., 1969. Symbolic interactionism: perspective and method. ISBN 978-0138799243. OCLC 18071 ed. Englewood Cliffs, N.J.: Prentice-Hall.

Cole, H. M. \& Ross, D., 1977. The arts of Ghana. Los Angeles: UCLA... Los Angeles: UCLA.

Dzobo, N. K., 2009. Dzobo, N.K. (2009) African symbols and proverbs as source of knowledge and truth... [Online].

Gardner, P., 1970. Symbolism (Greek and Roman. E.R.E., Volume 12, p. 138.

Geary, C. M., 1988. Messages and meaning of African court arts: Warrior figures from the Banum Kingdom. Art Journal, 47(2 Summer), p. $103-113$.

Gilbert, R., 1998. Living with Art. New York: McGraw-Hill Companies.

Giroux, H. A., 1983. Theory and Resistance in Education: A Pedagogy for the Opposition, South Hadley, MA: Bergin \& Garvey. 
Hill, S., 2006. Symbols and images in art have hidden meaning.

Kottak, C. P., 1991. Cultural Anthropology. USA: McGraw-Hill Inc.

Kyerematen, A. A. Y., 1964. Kyerematen, A. A. Y. (1964). Panoply of Ghana. Ornamental art in Ghanaian Tradition and Culture. New York: Praeger.

Kyerematen, A. A. Y., 1965. Panoply of Ghana. London: Longmans Green and Co. Ltd.

Moyeart, P., 2004. Worshipping of Idols and Images.

Nyathi, P., 2016. How The Chief's Regalia Sets Him Apart. THE SUNDAY NEWS, 29 May.

Pekeshe, M., 2016. Royal lineage begins at household level. THE PATRIOT, 30 June.

Pekeshe, M., 2014. Understanding origins and meaning of our royal regalia. The Patriot, 27 November.

Prown, J. D., 1993. The Truth of Material Culture: History or Fiction? History of Things: Essays on Material Culture. In Lubar and Kingeryeds eds ed. Washington: Smithsonian Institution Press.

Rattray, R. S., 1923. Rattray, R.S. (1923), Ashanti. London: Oxford University Press.

Rattray, S. S., 1927. Religion and Art in Ashanti. London: pp. London: Oxford University Press.

Sarpong, P. K., 1974. Ghana in retrospect; some aspects in Ghanaian culture. Accra: Ghana Publishing Corporation. 